\title{
Modelling of Nutrient Pollution Dynamics in River Basins: A Review with a Perspective of a Distributed Modelling Approach
}

\author{
Md Jahangir Alam ${ }^{1,2, *(1)}$ and Dushmanta Dutta ${ }^{3}$ \\ 1 Basin Strategy and Knowledge Portfolio, Murray Darling Basin Authority (MDBA), \\ Canberra, ACT 2601, Australia \\ 2 School of Civil Engineering and Surveying, University of Southern Queensland (USQ), \\ Toowoomba, QLD 4350, Australia \\ 3 Land and Water Division, NSW Department of Planning, Industry and Environment (DPIE), \\ Parramatta, NSW 2150, Australia; Dushmanta.Dutta@dpie.nsw.gov.au \\ * Correspondence: mjalam@gmail.com or Jahangir.Alam@mdba.gov.au or Mdjahangir.Alam@usq.edu.au
}

\section{check for} updates

Citation: Alam, M.J.; Dutta, D. Modelling of Nutrient Pollution Dynamics in River Basins: A Review with a Perspective of a Distributed Modelling Approach. Geosciences 2021, 11, 369. https://doi.org/ 10.3390/geosciences11090369

Academic Editors: Eun Young Lee, Annarita D'Addabbo,

Dimitrios Piretzidis and

Jesus Martinez-Frias

Received: 9 July 2021

Accepted: 25 August 2021

Published: 1 September 2021

Publisher's Note: MDPI stays neutral with regard to jurisdictional claims in published maps and institutional affiliations.

Copyright: (c) 2021 by the authors. Licensee MDPI, Basel, Switzerland. This article is an open access article distributed under the terms and conditions of the Creative Commons Attribution (CC BY) license (https:/ / creativecommons.org/licenses/by/ $4.0 /)$.

\begin{abstract}
Nutrient pollution is one of the major issues in water resources management, which has drawn significant investments into the development of many modelling tools to solve pollution problems worldwide. However, the situation remains unchanged, even likely to be exacerbated due to population growth and climate change. Effective measures to alleviate the issues are essential, dependent upon existing modelling tools' capacities. More complex models have been developed with technological advancement, though applications are mainly limited to academic reach. Hence, there is a need for a paradigm shift in policymaking that looks for a reliable modelling approach. This paper aims to assess the capacity of existing modelling tools in the context of process-based modelling and provide a future direction in research. The article has categorically divided models into plot scale to basin-wide applications for evaluation and discussed the pros and cons of conceptual and process-based modelling. The potential benefits of distributed modelling approach have been elaborated with highlights of a newly developed distributed model and its application in catchments in Japan and Australia. The distributed model is more adequate for predicting the realistic details of pollution problems in a changing environment. Future research needs to focus on more process-based modelling.
\end{abstract}

Keywords: nutrient pollution dynamics; soil erosion; surface runoff; distributed hydrological model; river network

\section{Background}

Nutrient pollution affects the surface and groundwater quality predominantly. Nitrogen $(N)$ and phosphorus $(P)$ are key nutrients that have been responsible for many forms of environmental hazards in aquatic ecosystems affecting the various states of amenities such as fisheries, navigation, water sports, and drinking water supply [1]. The use of chemical fertiliser for crop growing, pasture grazing, and livestock and dairy industry wastes have been responsible for $N$ and $P$ pollution in waterways [2]. Severe soil erosion is also associated with nutrient pollution in many landscapes [3]. The deforestation and modernisation of human societies are exacerbating the pollution effects. The global nutrient cycle has been altered substantially [1], and the anthropogenically derived atmospheric $N$ in the 2000s was ten times higher than that of the 1860s [4-7]. In the United Kingdom, rural pollution contributed $50 \%$ of $P$ inputs and $71 \%$ of $N$ loads to surface water in $2002[1,8]$. The toxic algal bloom outbreak has increased in the Murray-Darling basin, the largest basin in Australia, which has vast socioeconomic and environmental impacts [9]. The available trend and evidence of widespread excess nitrate concentration above the World Health Organization $(\mathrm{WHO})$ drinking water guideline in aquifers of many OECD countries indicate worsening groundwater quality [10]. The evidence suggests the need for drastic measures 
to recover polluted ecosystems, which substantially depend on current-day models' ability in decision support roles.

The consequences of burning fossil fuels are also felt in nutrient pollution. Climate change is likely to intensify the nutrient level in surface water [11]. The climate-driven atmospheric nitrogen deposition has exceeded the critical level in many European ecosystems $[12,13]$. The situation can be similar in other parts of the world, such as the United States [14]. However, atmospheric deposition may not be a significant source for many ecosystems such as Australia. Poor land management, land-use change (excessive land clearance), and poor stream management have aggravated the situation $[15,16]$.

With the emergence of numerous problems associated with regional-scale land-use management, global climate change, ecosystem functions, and pollutants' fate, the need for integrated environmental modelling (IEM) is increasing [17]. As the concept develops and organises multidisciplinary knowledge, it provides a means to explain, explore, and predict environmental system responses to natural and human-induced stressors [17]. However, many of the existing modelling tools are not suitable to predict the realistic details as necessary, resulting in inaccurate estimation of nutrient budgets globally [18]. The recommendation for further studies from national and international organisations highlighted the need for model developments with future research directions, including priorities for integrated modelling. For example, the European Water Framework Directive (EU WFD) urged the member states of the European Union to quantify and monitor nutrient pollution in their river systems, which necessitated the development of more suitable models such as MONERIS [19]. The Australian government's first five-year plan (1995-2000) National Eutrophication Management Program (NEMP) highlighted the need for process-oriented modelling [20]. Due to the lack of a proper model, the effects of upstream flow process and in-stream mechanism on blue-green algal growth remain unknown for many Australian river systems [21]. The demand for integrated environmental modelling (IEM) has grown in the context of regional-scale land-use management, global climate change impact assessment, valuations of ecosystem services, fate and transport of nanomaterials, and life-cycle analysis [17]. This sees the undertaking of studies on the determination of research directions and priorities for integrated modelling by various organisations around the globe [22-26].

Many past technical reviews provided future directions in research. In 2003, Borah and Bera [27] comprehensively reviewed 11 nonpoint source models to understand their appropriateness in evaluating watershed management practices. The study identified models for short-term and long-term event simulations. Bennet et al. [28] used environmental models' characterisation techniques to establish an appropriate level of confidence in model performance as they are used in research, management, and decision making. They used numerical, graphical, and qualitative methods for comparison of model performance. Fu et al. [29] reviewed existing catchment-scale water quality models of freshwater, nonurban systems and their ability to support catchment management. Their study identified a significant challenge in separating the impact of climate from land use and management and stressed the need for process-based modelling. In this study, we highlight the needs for process-based modelling from the technical point of view, whereas the previous review by Fu et al. [29] mainly focused on policy needs. Here, we identify models based on categories from source level to basin-wide application and highlight the prospect of process-based modelling compared with others, particularly the capacity in determining the fate of nutrients in higher temporal and spatial resolutions and dealing with climate change applications.

\section{The Review of Existing Models}

The existing modelling tools are discussed broadly under three categories. The first category describes the plot-scale models, mainly used to determine pollutant loads from agricultural areas. Many of these models are the basis for larger-scale application input, forming the critical foundation for integrated modelling. The river network models are 
discussed under the second category. Finally, the third category identifies integrated models that combine land surface and in-stream network processes for holistic modelling of the watershed.

The atmospheric deposition of $N$ nutrient is one of the sources for nutrient enrichment in many agricultural watersheds in some regions [12,13], and it can be modelled by using tools such as Model of Atmospheric Transport and Deposition of Reacting Nitrogen (MATADORN); long-range element tracer models HARM and TRACE [30,31] are excluded in the review below.

\subsection{Nonpoint Source (NPS) Models at the Plot Scale}

The early development of nonpoint source models mainly focused on solving pollution problems arising from agricultural land as the issue with the extensive use of chemical fertiliser was growing. Since both $N$ and $P$ have detrimental effects on ecology, the concern has developed on reducing $N$ and $P$ loading from agricultural catchments to river systems [32]. The plot-scale NPS models assist in identifying best management practices. However, in most cases, simplistic approaches such as export coefficient or the event mean concentration methods were used and considered acceptable approaches [33]. The Pollutant Load (PLOAD) [34] model is an example of this type of model. Chemicals, Runoff, and Erosion From Agricultural Management Systems (CREAMS) [35] and GLEAMS [36] are similar models but use some physics-based approaches. The processbased approach is found in Soil Nitrogen (SOIL N) and Soil Plant Atmosphere System (DAISY) models. In the SOIL $N[37,38]$ model, the nutrient transformation process is considered conceptually, but the soil transformation process is divided into different layers in a mechanistic way $[39,40]$, which is helpful in the study of the hydro-climatic influence on nutrient release. DAISY [41-43] adopted a more robust approach in describing the soil-plant-atmosphere interaction designed to simulate $N$ dynamics in agricultural soils, which is suitable for simulating crop pattern behaviour on the nutrient level. The Root Zone Water Quality Model (RZWQM) [44-48] and Leaching Estimation and Chemistry Model (LEACHM) [40] are some other plot-scale models for the analysis of root zone process and groundwater leaching.

\subsection{The River Water Quality Models}

The in-stream water quality models are mainly used for determining the fate of pollutants during transport in flowing water. In this kind of modelling, the input is the point discharge at the river upstream or tributary locations. The models output the concentration level of pollutants at different segments of the channel. An example of a widely used stream water quality model is QUAL2K [49] or the improved version QUAL2E [50,51], which simulates state variables at river reaches based on wastewater loading as input for the model. QUAL2K and QUAL2E solve the equations for physical transport and chemical reaction processes of nutrients; however, the steady-state models provide output at a diel time scale only [49].

MIKE11 WQ is a one-dimensional river water quality modelling software that overcomes the limitation of a steady-state model by solving dynamic equations for physical, chemical, and biological processes. The model describes pollutant's interaction with bed load sediment and organisms, including nitrification and denitrification for computing dissolved oxygen (DO), biochemical oxygen demand (BOD), ammonia, and nitrate [52]. The tool adopts Nitrogen Simulation Model DRAINMOD-N to calculate nitrate input from agricultural land with other source inputs for the MIKE11 model [53].

The International Water Association (IWA) River Water Quality Model No. 1 (RWQM1) overcomes the limitations of the BOD-based river water quality models. This model incorporates biomass population growth and respiration processes to deal with the river acclimatisation to changes in pollutant load or environmental conditions and tracks mass continuity by describing the composition of organic material as the mass fraction of organic compounds [54]. In addition, the RWQM1 was a useful simulation tool for CalHidra2.0 
to analyse the $N$ removal and study different scenarios, including upgrading several wastewater treatment plants (WWTPs) [54].

\subsection{Basin-Scale Integrated Models}

The large-scale models aim to integrate land surface and in-stream processes in more detail. The main features in this type of modelling are the amalgamation of components to describe the whole basins. As a result, we found a mix of approaches to describe catchment behaviours in many basin-scale models.

\subsubsection{Conceptual Models at Basin Scale}

Agricultural Non-point Source Pollution model (AGNPS) [55] is a basin-scale single event-based model estimating pesticide and nutrient runoff from nonpoint sources in the agricultural watershed [56]. The model uses the empirical equation-based method. The AnnAGNPS is an improved version model of AGNPS, developed by the U.S. Department of Agriculture Agricultural Research Service (USDA-ARS) [57-59]. This version is capable of continuous simulation of nonpoint pollutants at a yearly scale [60]. A similar type of model, Areal Non-point Source Watershed Environment Response Simulation (ANSWERS) [61,62], computes movement of water in overland, subsurface, and channel flow phases operating on a cell-to-cell basis [63-65]. However, AGNPS and ANSWERS are single event-based models, and the application is limited to watersheds of about $200 \mathrm{~km}^{2}$ [66].

Catchment Scale Management of Diffuse Source (CatchMODS) [67] is a semidistributed model that uses the Identification of Unit Hydrographs and Component Flows from Rainfall, Evaporation, and Streamflow (IHACRES) hydrological model [68] for calculating the time-series input of catchment boundary conditions. The sediment component is similar to SedNet model [69]. The model outputs are TN and TP on an annual basis without considering different species of nutrients due to a lack of process description $[67,70]$.

Modelling Nutrient Emissions in River Systems (MONERIS) [71] is a conceptual model to account for different sources of nutrient emission [72]. The model considers seven pathways of inputs to the river network. The model is applicable for the estimation of annual loads. Monthly simulation is in progress (anonymously).

The stochastic model Spatially Referenced Regressions on Watershed Attributes (SPARROW) is a spatially referenced regression model that examines the landscape characteristics influencing the delivery of $N$ and $P$ from sources in a watershed to stream channels [73]. The approach in the model to determine the capacity of a watershed to deliver $N$ to channels is the use of a 'landscape delivery ratio' (LDR), which is expressed as the fraction of $N$ input that completes the overland and subsurface phase of transport to the stream channel. When the landscape delivery ratio is modelled, it is considered as a continuous function of local-scale landscape characteristics. Then, a spatial pattern is estimated that varies as a function of soil and climate characteristics. Subsequent incorporation of regional frameworks, such as physiographic, geologic, or ecological regions, may improve the estimation of landscape delivery ratio that is useful in modelling the effects of relatively broad-scale spatial processes that affect $N$ attenuation [73]. The multivariate statistical techniques, such as cluster analysis (CA), principal component analysis (PCA), factor analysis (FA), and discriminant analysis (DA) can help characterise and evaluate surface and freshwater quality and verify temporal and spatial variations caused by natural and anthropogenic factors linked to seasonality [74,75].

The Australian modelling software developer the eWater has developed a suite of modelling packages such as CMSS [76], Environmental Management Support System (EMSS), the catchment modelling framework E2, and Water and Contaminant Analysis and Simulation Tool (WaterCAST) for various applications $[70,77,78]$. The Catchment Management Support System (CMSS) is an accounting model for nutrient budgeting from different land-use types [79], the EMSS is an event mean concentration and dry weather concentration based simulation model [80,81], and E2 and WaterCAST are improved versions for continuous time series simulations at catchment scale. The Catchment-Stream 
Water Quality model CatStream [82,83] is another conceptual and network-based integrated catchment-stream water quality model built on a simplistic export coefficient method. The spatial scale is on a subcatchment basis, and the temporal scale is daily. The model outputs are TSS, TN, and TP. The main limitation of export coefficient-based modelling is the lack of representation of inherent processes, which makes the models unsuitable for predicting changes in hydro-climatic conditions.

\subsubsection{Process-Based Models at Basin Scale}

The process-based models aim to overcome conceptual modelling limitations by incorporating process descriptions from source generations to pollutant movement in surface and subsurface zones. For example, the Integrated Catchment Model of Nitrogen Dynamics (INCA-N) [30,31] is a process-based semidistributed model that estimates nutrient flux in soil and groundwater zones and tracks movements of both nitrate $\mathrm{N}$ and ammonium $\mathrm{N}$ in the riverine phase. The Integrated Catchment Model of Phosphorus Dynamics (INCA-P) is a similar type of model for $\mathrm{P}$ simulation and has a very complex and detailed description of $P$ processes $[84,85]$. Although INCA-N and INCA-P are physically based models for $N$ and $P$ in the catchment and riverine phases, the hydrological part is conceptual. Therefore, they may not suit predictions under changing environments.

The stream order-based model RIVERSTRAHLER [86,87] simulates river eutrophication and in-stream algal production based on the ecological function of the river systems. It links the kinetics of microbiological and chemical processes to their macroscopic appearance at the scale of the whole drainage network [86,88-91].

The Pollutant Flow (PolFlow) model, developed in GIS, adopts a distributed modelling approach that calculates nutrient fluxes, routes nutrients through the river network, and has dynamic functions to account for nutrient transport delay in the soil groundwater [92]. However, the model operates in five-year time steps using spatial function at a spatial resolution of $1 \mathrm{~km}^{2}$, which may not suit current situations.

The real-time flood forecasting system WATFLOOD [93] is a distributed model that uses group response unit functions to describe the hydrological process. The model estimates runoff, sediment yield, and soluble nutrient concentrations for each land cover class, weighted by area and then routed downstream. However, the model has a limitation in describing the transport process as it does not include a dedicated river component.

The Soil and Water Assessment Tool (SWAT) model [94,95] is an outcome of the USDA Agricultural Research Service (ARS). The origin of SWAT is linked to USDA ARS models, including the CREAMS [96], GLEAMS [36,97], and the Environmental Impact Policy Climate (EPIC) [98]. The EPIC was initially called the Erosion Productivity Impact Calculator [99]. These components were previously combined into a simulator called the Water Resources in Rural Basins (SWRRB) model [100] to assess management impacts on water and sediment movement for ungauged rural basins across the United States. The SWAT has been widely used around the world for its easy access and flexibility [101]. For example, the Ecohydrological Assessment Tool (ECOHAT) combined SWAT with a conceptual rainfall-runoff model Xinanjiang for modelling the Chinese watersheds [102].

The Diffuse Nitrate Modelling Tool (DNMT) [32] is built within the TOPMODEL [103] for simulation of runoff through the permeable area and over the impervious area and the nitrate transport. The $N$ transformation process has been modelled using SOILN [38]. However, this model introduced the unit nitrograph (UNG) method, similar to the concept of the unit hydrograph method in hydrology, which is based on a conceptual approach.

The MATSALU model was developed in Estonia for the Matsalu Bay (Baltic Sea) agricultural watershed to assess different management scenarios for eutrophication control of the bay $[104,105]$. The model consists of four coupled submodels that simulate watershed hydrology, catchment geochemistry, river transport of water and nutrients, and the bay ecosystem. Like SWAT, its watershed components were essentially based on the CREAMS approach. However, since the model was developed for the MATSALU watershed and connected to specific datasets, it is not sufficiently transferable. 
The Soil and Water Integrated Model (SWIM) is a watershed model for hydrology and water quality that combines SWAT and MATSLU models and was suggested for $N$ modelling for mesoscale watersheds $\left(100-10,000 \mathrm{~km}^{2}\right)$ [66].

An integrated surface and subsurface model (ISSM) was applied in the Bonello watershed in Italy; it incorporated a hydrological model (SWAT), groundwater models (MODFLOW and MT3DMS), and an in-stream water quality model (QUAL2E). The tool provides good results in predicting water and nutrient leaching from the surface to the aquifer, groundwater dynamics, aquifer interaction with the stream system, and the surface water and nutrient fluxes at the watershed outlet [106].

The Système Hydrologique Européen Transport (SHETRAN) [107,108] model couples the surface/subsurface three-dimensional water flow, multifraction sediment transport, and multiple reactive solute transport. The leaching and transport of nitrate are modelled using the three-dimensional differential solute transport equations [109,110]. Using SHETRAN-UK, a nitrogen modelling system (NMS) was developed and applied within the $3000 \mathrm{~km}^{2}$ Tyne basin from 1985 to 1989 . The physically based catchment model NMS comprises a field-scale nitrogen model, EPIC. EPIC is an established crop growth and farm management model [111] and provides $N$ input and uptake data to SHETRAN [112].

MIKESHE, a submodel of SHE Système Hydrologique Européen, within the MIKE framework from the Danish Hydraulic Institute (DHI), was combined with DAISY to estimate pesticide leaching to shallow groundwater for physically based simulation of macropore flow process in a spatially distributed manner [113-116]. Similarly, the European Soil Erosion Model EUROSEM [117,118] was combined with MIKESHE for continuous simulation. MIKESHE is a physically based distributed hydrological modelling tool $[107,108]$. However, the use of MIKESHE may not be applicable where the hydrologic regime is dominated by overland flow [113].

\section{Research Gap Analysis over Basin-Scale Modelling}

The watershed models provide a useful framework for analysing the anthropogenic and climate effects on the natural environment [66]. Many of these models have been developed, dividing the catchment into homogeneous subareas called hydrologic response units (HRUs). Each HRU consists of parameters for the topographic features, land use, land cover, and soil types. Models such as SWRRB [119], MATSALU [104,105], and SWAT [120] have used the concept of HRU for larger watershed-scale modelling. The size of a watershed is also a factor for the applicability of some models in some instances. It is found that SWRRB can be used in agricultural basins of up to $600-800 \mathrm{~km}^{2}$, MATSALU was applied in a $3500 \mathrm{~km}^{2}$ rural basin, and SWAT was applied in watersheds of up to $25,000 \mathrm{~km}^{2}$ in the United States [66]. Hence, it is apparent that some models are catchment-specific due to limitations in HRU approaches. The main drawback is that the water flows and dissolved and solid-phase concentrations of nutrient compounds are computed from lumped hydrologic and biogeochemical processes at a subarea (HRU), which may not be applicable to larger catchments. As a result, the need for distributed modelling is evident for regional-scale application for water quantity and quality analysis.

In many modelling tools, the nutrient transport via soil erosion process has been ignored, which could be an important source in many watersheds. The WATFLOOD [93,121] model separates soil-bound and soluble nutrient transport processes in the model description, though there are limitations in the transport mechanism that need to be addressed [93]. The SWAT model [95] is not suitable for dynamic sediment modelling [122]. Hence, the linking of hillslope soil erosion process and in-stream sediment transport has been an important research topic in the nutrient modelling context.

ANIMO [123] and DAISY [42,43] are examples of complex mathematical models that could be useful to describe nitrogen biogeochemical process in a detailed manner; however, they are limited to application in soil column movement only at plot-scale levels as they do not include a component for movement or transformation in surface water or groundwater [112]. The integration of this type of plot scale model with a distributed hydrologic 
model such as MIKESHE or SHETRAN could overcome the limitations. As the computing facilities and GIS functionalities have advanced tremendously, spatially distributed models have been linked with catchment and drainage network systems for continuous time series simulation [124-127]. The fully distributed hydrological model MIKESHE [107,108] has incorporated DAISY, and the similar model SHETRAN incorporated NMS for a physically based description of nutrient dynamics for nitrate simulation. However, their applications were mainly limited to groundwater analysis. The distributed modelling of dominant overland flow process and nutrient export from catchment to the river network system via various pathways are very limited.

Human-induced climate change has far-reaching consequences with negative impacts on the ecosystem from local to global level [11]. Overexploitation of natural resources, population growth, and urbanisation are linked to degraded water quality in surface and ground waters. Climate change will place additional stress on receiving watercourses through alterations to rainfall and temperature and resultant changes in biophysical properties [128]. The uncertainties of how future climate will alter physical, chemical, and biological systems combined with uncertainties of climate models limit our ability to provide robust predictions and identify how best to manage the water environment [129]. Such uncertainties make it difficult to determine future water quality status and set improvement targets to achieve good ecological outcomes [130].

The authors of this paper adopted a process-based approach in nutrient simulation with an aim to improve model predictions, developed within a distributed hydrological modelling framework IISDHM [131-133], and demonstrated how hydro-climate-based parameters were useful to assess the impact of climate change on nutrient pollution and determine the future water quality status [134]. An overview of this modelling is discussed below, and summaries of all models reviewed in this paper are presented in Tables A1-A3 (Appendix A).

\section{Applicability of a Distributed Modelling Approach within IISDHM}

The Institute of Industrial Sciences Distributed Hydrological Model (IISDHM) is a distributed hydrological model, originally developed at the University of Tokyo, Japan [131-133], that can describe the hydrological process in surface and subsurface zones. Authors Alam and Dutta [134-136] developed the nutrient modelling components within this IISDHM framework. Figure 1 shows the various components of the model.

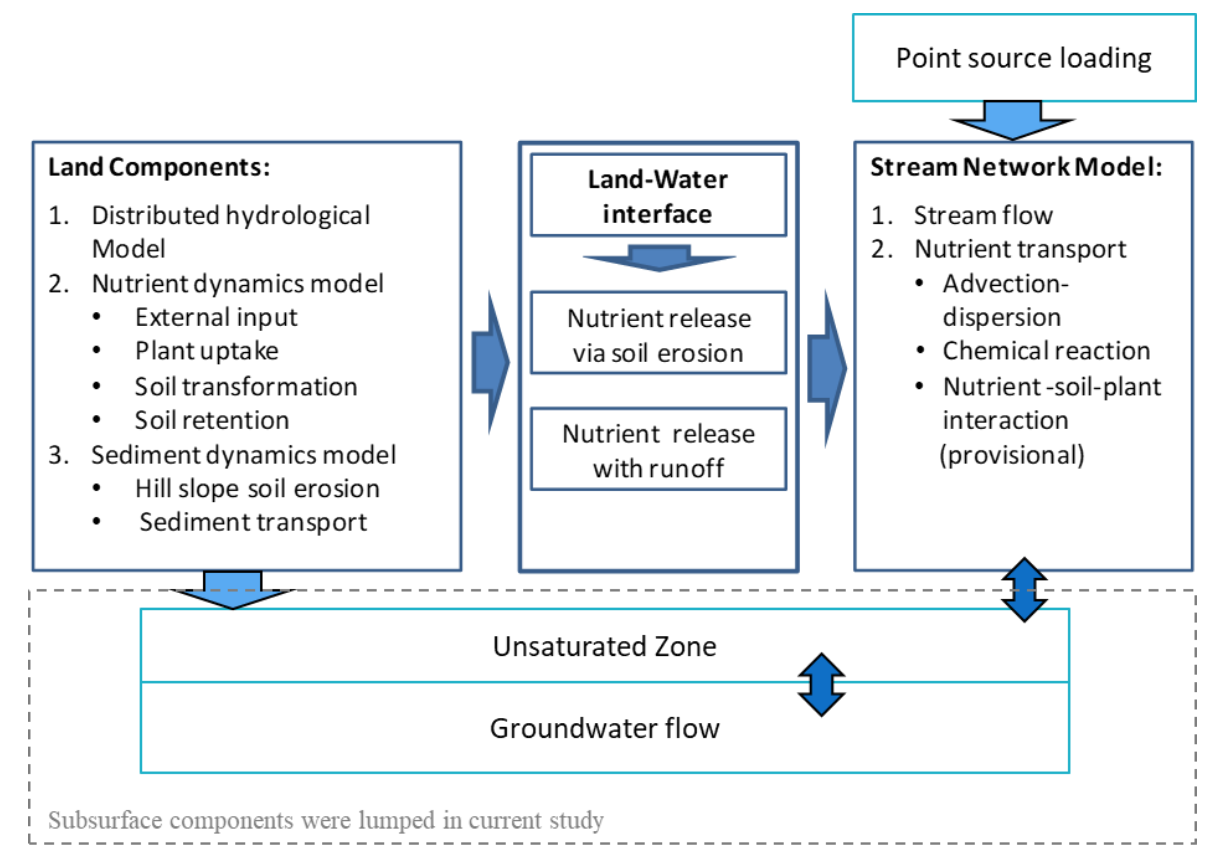

Figure 1. Integrated modelling framework for nutrient dynamics and transport. 
The model was tested and verified in two case studies in Japan and Australia (Figure 2), which are hydro-climatologically of distinct characteristics, being situated in different hemispheres. The size of the catchment of the Saru River of Japan is about $1350 \mathrm{~km}^{2}$. Although the catchment is predominantly a forested ecosystem, huge amounts of sediment and nutrient loads are carried away during heavy floods.

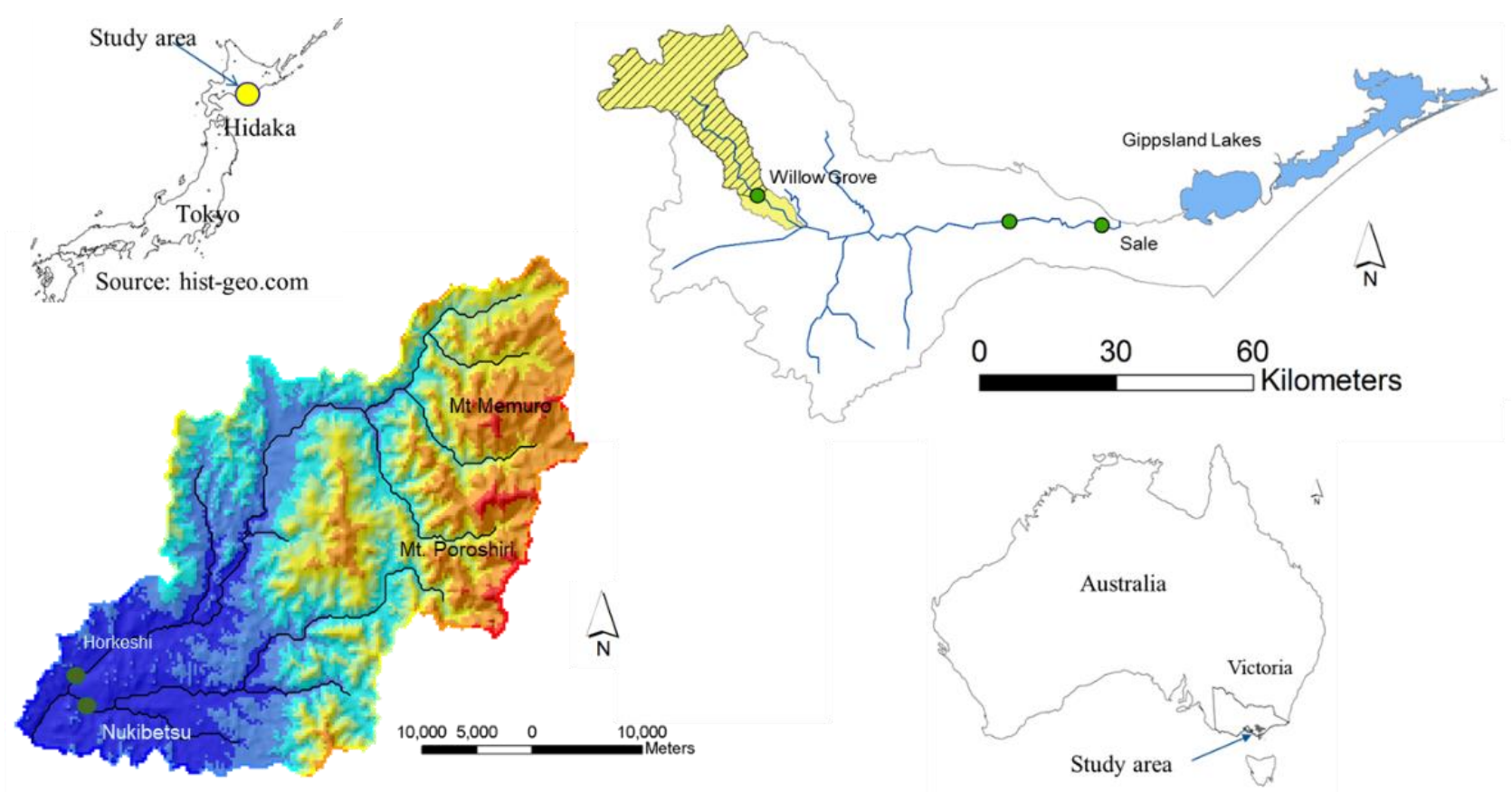

Figure 2. Location maps showing case study areas (the Saru River, Japan (left) and the Latrobe River, Australia (right).

As data were available from a high-intensity data collection campaign, the applicability of the model for flash flood events could be tested in the Saru River. The observed data show strong correlations between flow and nutrient level for this river, as shown in Figure 3, which was predicted well with hourly interval output.
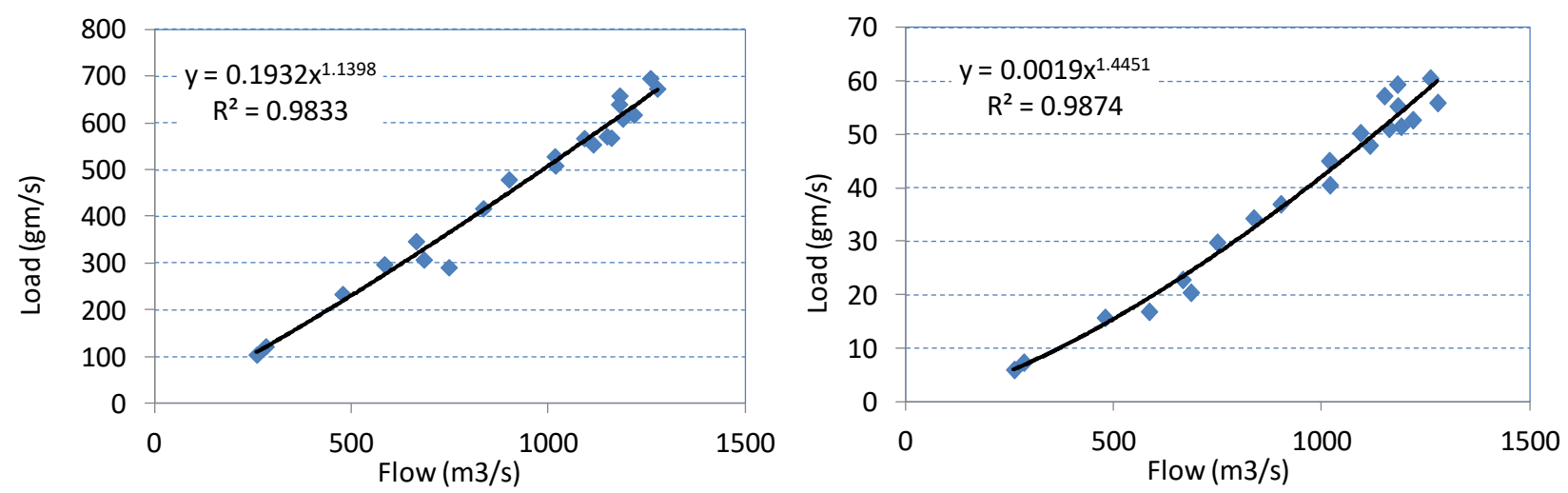

Figure 3. Correlation of $\mathrm{NO}_{3}-\mathrm{N}$ (left) and $\mathrm{PO}_{4}-\mathrm{P}$ (right) loadings with flow in the Saru River.

The model adopted hydro-climate-based parameters and soil moisture index, which was useful to simulate seasonal nutrient transport behaviours for the Latrobe River in Australia. Figure 4 shows the seasonal pattern of $\mathrm{NO}_{3}-\mathrm{N}$ level and the correlation with the flow that was used for model validation. 

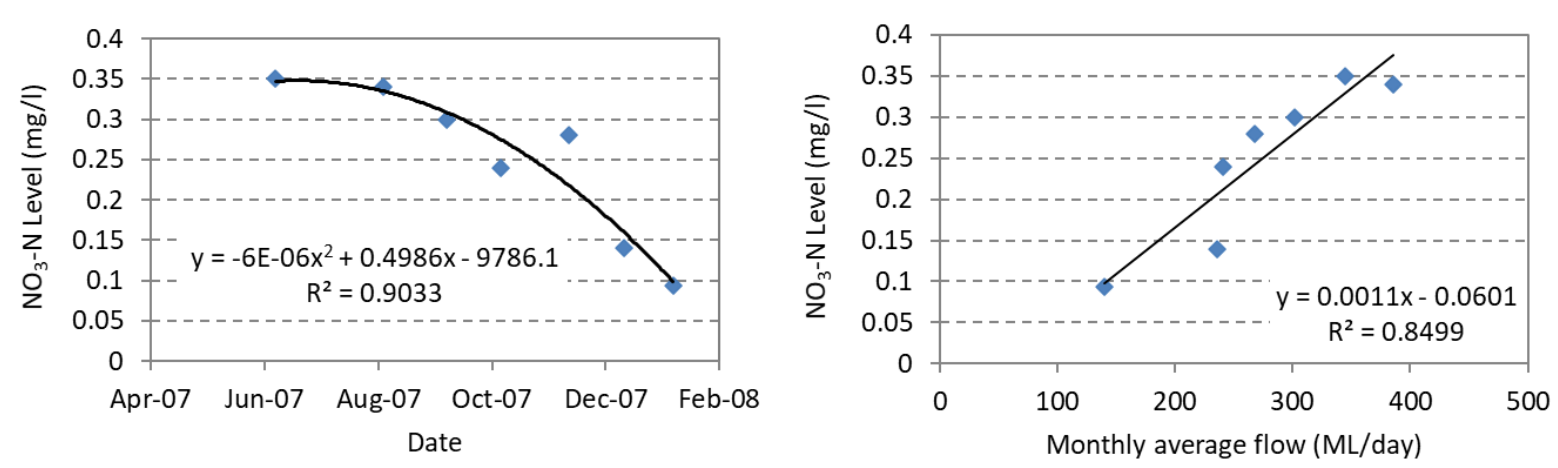

Figure 4. Seasonal pattern in $\mathrm{NO}_{3}-\mathrm{N}$ level and the correlation with the flow in the upper catchment of the Latrobe River.

\section{Conclusions}

A comprehensive review of the existing nutrient modelling tools has been presented in this paper. The discussion has covered various types of models, including plot-scale models, river water quality models, and basin-scale integrated models. It is observed that the conceptual approach using the export coefficient method or event mean concentration method is a widely used approach in determining nutrient release from different land uses. These methods are best suited for assessing best management practices by accounting for annual loadings of $T N$ and $T P$ from agricultural lands. However, this type of modelling is unsuitable for predicting dynamic behaviour due to changes in catchment processes. The process-based models overcome the limitations, though their application has been very limited to agricultural lands, where they have mostly been used to determine the nutrient level for plant growth interaction or groundwater modelling. The implementation at a larger scale is relatively scarce because of the inability to describe the proper nutrient export mechanism. Future research should focus on integrating catchment and river transport modelling that enables the determination of catchment export, the residence or movement of nutrients in various pathways, and the role of sediment in nutrient budgeting at downstream waters. This study shows an application of a distributed modelling approach that was useful to predict nutrient pollution at a detailed level under a changing environment. This type of modelling will be helpful to determine the future water quality status and adopt management options for integrated planning.

Author Contributions: Conceptualization, M.J.A.; methodology, M.J.A.; validation, M.J.A.; formal analysis, M.J.A.; investigation, M.J.A.; resources, M.J.A.; writing—original draft preparation, M.J.A.; writing - review and editing, M.J.A. and D.D.; supervision, D.D.; All authors have read and agreed to the published version of the manuscript.

Funding: This research received no external funding. The study was supported by a PhD scholarship (completed in 2013) from Monash University and Australian Government (Australian Postgraduate Award). The article processing charge (APC) was funded by Geosciences, MDPI.

Data Availability Statement: Not applicable.

Acknowledgments: This paper is based on PhD research undertaken at Monash University, Australia. The data for the Saru River was available from the Kitami Institute of Technology and the IISDHM from the University of Tokyo, Japan. Victorian government's online water data portal Data Warehouse was the data source for the Latrobe River case study. Authors are highly grateful to anonymous reviewers and others for their valuable suggestions.

Conflicts of Interest: The authors declare no conflict of interest. The research was not part of any projects related to authors' current affiliated organisations. 


\section{Appendix A}

Table A1. The summary of plot-scale models.

\begin{tabular}{|c|c|c|c|c|c|c|}
\hline Name of Model & Type & $\begin{array}{l}\text { Land Surface } \\
\text { Process }\end{array}$ & $\begin{array}{c}\text { Ground Water } \\
\text { Process }\end{array}$ & Temporal Scale & Output & Reference \\
\hline PLOAD & Conceptual & $\begin{array}{c}\text { Export } \\
\text { coefficient }\end{array}$ & - & Annual & $T N$ and $T P$ & {$[34]$} \\
\hline LEACHM & Process based & $\begin{array}{l}\text { Soil and crop } \\
\text { model }\end{array}$ & $\begin{array}{l}\text { Unsaturated } \\
\text { zone model }\end{array}$ & Variable time & $N$ and $P$ & {$[40,137]$} \\
\hline SOILN/SOILNDB & Process based & $\begin{array}{l}\text { Soil and crop } \\
\text { model }\end{array}$ & Lumped & Annual & $N$ & {$[17,38,109,138]$} \\
\hline EPIC & Process based & $\begin{array}{l}\text { Soil and crop } \\
\text { model }\end{array}$ & - & Annual & $N$ and $P$ & [123] \\
\hline ANIMO & Process based & $\begin{array}{c}\text { Soil layer } \\
\text { model }\end{array}$ & Leaching & $\begin{array}{l}\text { Variable time } \\
\text { step }\end{array}$ & $N$ species & {$[99,123]$} \\
\hline CREAMS/GLEAMS & Physics & Soil and crop & Root zone & Event based & $N$ and $P$ & {$[35,36,96,97]$} \\
\hline RZWQM & Process based & $\begin{array}{l}\text { Soil and crop } \\
\text { model }\end{array}$ & Lumped & Subdaily & $\mathrm{NO}_{3}-\mathrm{N}$ & [46] \\
\hline DAISY & Process based & $\begin{array}{l}\text { Soil and crop } \\
\text { model }\end{array}$ & Leaching & Variable time & $\mathrm{NO}_{3}-\mathrm{N}$ & [41-43] \\
\hline
\end{tabular}

Table A2. The summary of river water quality models.

\begin{tabular}{|c|c|c|c|c|c|c|c|c|}
\hline Name of Model & Type & $\begin{array}{c}\text { Land Surface } \\
\text { Process }\end{array}$ & $\begin{array}{c}\text { In-Stream } \\
\text { Process }\end{array}$ & $\begin{array}{l}\text { Ground } \\
\text { Water } \\
\text { Process }\end{array}$ & $\begin{array}{l}\text { Spatial } \\
\text { Scale }\end{array}$ & $\underset{\text { Scale }}{\text { Temporal }}$ & Output & Reference \\
\hline $\begin{array}{l}\text { QUAL2K/ } \\
\text { QUAL2E }\end{array}$ & $\begin{array}{c}\text { Process } \\
\text { based }\end{array}$ & $\begin{array}{c}\text { Time series } \\
\text { input }\end{array}$ & $\begin{array}{c}\text { Network } \\
\text { model }\end{array}$ & - & River reach & $\begin{array}{c}\text { Diel time } \\
\text { scale }\end{array}$ & $\begin{array}{c}N \text { and } P \\
\text { species }\end{array}$ & [49-51] \\
\hline MIKE 11 & $\begin{array}{c}\text { Process } \\
\text { based }\end{array}$ & $\begin{array}{c}\text { Time series } \\
\text { input }\end{array}$ & $\begin{array}{c}\text { Network } \\
\text { model }\end{array}$ & - & $\begin{array}{l}\text { Node and } \\
\text { link }\end{array}$ & $\begin{array}{l}\text { Variable time } \\
\text { step }\end{array}$ & $\begin{array}{l}N \text { and } P \\
\text { species }\end{array}$ & [139] \\
\hline $\begin{array}{c}\text { RWQM1; } \\
\text { CalHidra 2.0 }\end{array}$ & $\begin{array}{l}\text { Process } \\
\text { based }\end{array}$ & Exist & Exist & - & $\begin{array}{l}\text { Node and } \\
\text { link }\end{array}$ & Not available & $N$ and $P$ & [54] \\
\hline INCA-N & $\begin{array}{c}\text { Process } \\
\text { based }\end{array}$ & Semidistributed & Reach based & Semidistributed & River reach & Weekly & $\mathrm{NO}_{3}-\mathrm{N}$ level & {$[30,31]$} \\
\hline INCA-P & $\begin{array}{l}\text { Process } \\
\text { based }\end{array}$ & Semidistributed & Reach based & Semidistributed & River reach & Daily & $\begin{array}{c}\text { Organic and } \\
\text { inorganic } P \\
\text { levels }\end{array}$ & [85] \\
\hline RIVERSTRAHHLER & $\begin{array}{l}\text { Process } \\
\text { based }\end{array}$ & - & $\begin{array}{c}\text { River } \\
\text { network } \\
\text { model }\end{array}$ & - & River reach & Variable time & $\begin{array}{c}\text { Nitrate, } \\
\text { phosphates, } \\
\text { and silica }\end{array}$ & [86] \\
\hline
\end{tabular}

Table A3. The summary of integrated basin-scale models.

\begin{tabular}{|c|c|c|c|c|c|c|c|c|}
\hline $\begin{array}{l}\text { Name of } \\
\text { Model }\end{array}$ & Type & $\begin{array}{l}\text { Land } \\
\text { Surface } \\
\text { Process }\end{array}$ & $\begin{array}{l}\text { In-Stream } \\
\text { Process }\end{array}$ & $\begin{array}{l}\text { Ground } \\
\text { Water } \\
\text { Process }\end{array}$ & Spatial Scale & $\begin{array}{l}\text { Temporal } \\
\text { Scale }\end{array}$ & Output & Reference \\
\hline CatStream & Conceptual & Subcatchment & $\begin{array}{c}\text { River } \\
\text { network }\end{array}$ & - & $\begin{array}{l}\text { Subcatchment } \\
\text { based }\end{array}$ & Daily & $\begin{array}{l}\text { TSS, TN, } \\
\text { and TP }\end{array}$ & {$[82,83]$} \\
\hline AGNPS & Physics & Rate based & - & - & $\begin{array}{c}\text { Grid } \\
\text { based-can be } \\
\text { used up to } \\
200 \mathrm{~km}^{2} \text { size } \\
\text { watershed }\end{array}$ & Single event & $N$ and $P$ & [55] \\
\hline ANSWERS & $\begin{array}{c}\text { Physically } \\
\text { based }\end{array}$ & $\begin{array}{l}\text { Sediment } \\
\text { and runoff } \\
\text { based }\end{array}$ & Exist & Exist & $\begin{array}{c}\text { Hydrologic } \\
\text { response unit } \\
(\mathrm{HRU}) \\
\left(200 \mathrm{~km}^{2}\right)\end{array}$ & Single event & $N$ and $P$ & {$[61,62]$} \\
\hline CatchMODS & Conceptual & $\begin{array}{c}\text { Time series } \\
\text { by IHACRES }\end{array}$ & $\begin{array}{l}\text { Network } \\
\text { model }\end{array}$ & $\begin{array}{l}\text { Leaching } \\
\text { estimates }\end{array}$ & $\begin{array}{c}\text { Subcatchment } \\
\text { based }\end{array}$ & Annual & $\begin{array}{c}T N \text { and } T P \\
\text { loads }\end{array}$ & [67] \\
\hline
\end{tabular}


Table A3. Cont.

\begin{tabular}{|c|c|c|c|c|c|c|c|c|}
\hline $\begin{array}{l}\text { Name of } \\
\text { Model }\end{array}$ & Type & $\begin{array}{l}\text { Land } \\
\text { Surface } \\
\text { Process }\end{array}$ & $\begin{array}{c}\text { In-Stream } \\
\text { Process }\end{array}$ & $\begin{array}{l}\text { Ground } \\
\text { Water } \\
\text { Process }\end{array}$ & Spatial Scale & $\underset{\text { Scale }}{\text { Temporal }}$ & Output & Reference \\
\hline CMSS & Conceptual & $\begin{array}{c}\text { Export } \\
\text { coefficient }\end{array}$ & - & - & $\begin{array}{l}\text { Subcatchment } \\
\text { based }\end{array}$ & Daily & $\begin{array}{c}T N \text { and } T P \\
\text { loads }\end{array}$ & [76] \\
\hline EMSS & Conceptual & $\begin{array}{l}\text { Event mean } \\
\text { concentra- } \\
\text { tion }\end{array}$ & - & - & $\begin{array}{l}\text { Subcatchment } \\
\text { based }\end{array}$ & Daily & $\begin{array}{c}T N \text { and } T P \\
\text { loads }\end{array}$ & [70] \\
\hline E2 & Conceptual & $\begin{array}{l}\text { Event mean } \\
\text { concentra- } \\
\text { tion }\end{array}$ & - & - & $\begin{array}{l}\text { Subcatchment } \\
\text { based }\end{array}$ & Daily & $\begin{array}{l}T N \text { and } T P \\
\text { loads }\end{array}$ & [77] \\
\hline SWRRB & $\begin{array}{l}\text { Physics } \\
\text { based }\end{array}$ & CREAMS & - & GLEAMS & $\begin{array}{c}\text { Basin scale } \\
\left(600-800 \mathrm{~km}^{2}\right)\end{array}$ & Single event & & [119] \\
\hline PolFlow & Conceptual & Lumped & Lumped & Lumped & $1 \mathrm{~km}$ grid & 5 year & $\begin{array}{c}T N \text { and } T P \\
\text { loads }\end{array}$ & [92] \\
\hline MONERIS & Conceptual & $\begin{array}{l}\text { Rate based } \\
\text { emission } \\
\text { from } \\
\text { different } \\
\text { sources }\end{array}$ & - & $\begin{array}{l}\text { Lumped as a } \\
\text { source }\end{array}$ & $1 \mathrm{~km}$ grid & Annual & $\begin{array}{l}T N \text { and } T P \\
\text { emission }\end{array}$ & [71] \\
\hline SPARROW & $\begin{array}{l}\text { Regression } \\
\text { model }\end{array}$ & $\begin{array}{l}\text { Landscape } \\
\text { delivery } \\
\text { ratio }\end{array}$ & $\begin{array}{l}\text { Network } \\
\text { model }\end{array}$ & Lumped & $\begin{array}{l}\text { River reach } \\
\text { with catchment } \\
\text { input }\end{array}$ & Annual & $T N$ & [73] \\
\hline DNMT & $\begin{array}{l}\text { Process } \\
\text { based }\end{array}$ & $\begin{array}{l}\text { SOILN } \\
\text { model }\end{array}$ & $\begin{array}{l}\text { Unit } \\
\text { Nitrograph } \\
\text { (UNG) } \\
\text { method for } \\
\text { transport to } \\
\text { waterways }\end{array}$ & $\begin{array}{l}\text { Lumped } \\
\text { with soil } \\
\text { nutrient } \\
\text { process } \\
\text { model } \\
\text { (SOILN) }\end{array}$ & $\begin{array}{l}\text { Subcatchment } \\
\text { based }\end{array}$ & $\begin{array}{l}\text { Multiple } \\
\text { steps }\end{array}$ & $\mathrm{NO}_{3}-\mathrm{N}$ & [32] \\
\hline SWAT & $\begin{array}{l}\text { Process } \\
\text { based }\end{array}$ & $\begin{array}{l}\text { Lumped soil } \\
\text { and aquifer } \\
\text { process }\end{array}$ & QUAL2E & $\begin{array}{l}\text { Lumped } \\
\text { with surface } \\
\text { process }\end{array}$ & $\begin{array}{l}\text { Semidistributed } \\
\text { variable } \\
\text { storage routing } \\
\text { method }\end{array}$ & $\begin{array}{l}\text { Variable } \\
\text { steps }\end{array}$ & $N$ & {$[94,95,140]$} \\
\hline MATSALU & & Same a & SWAT & & $\begin{array}{l}\text { Elementary } \\
\text { Areas of } \\
\text { Pollution } \\
\text { (EAP) based }\end{array}$ & Daily & $N$ & [105] \\
\hline SWIM & & Same a & SWAT & & $\begin{array}{l}\text { Mesoscale } \\
\text { watershed }\end{array}$ & Daily & $N$ & [66] \\
\hline ISSM & $\begin{array}{c}\text { Process } \\
\text { based }\end{array}$ & SWAT & QUAL2E & $\begin{array}{l}\text { MODFLOW- } \\
\text { MT3DMS }\end{array}$ & - & Daily & $N$ and $P$ & [106] \\
\hline WATFLOOD & $\begin{array}{l}\text { Process } \\
\text { based }\end{array}$ & $\begin{array}{l}\text { Group } \\
\text { response } \\
\text { unit (GRU) } \\
\text { approach; } \\
\text { CREAM and } \\
\text { AGNPS } \\
\text { approach }\end{array}$ & - & $\begin{array}{l}\text { Lumped to } \\
\text { estimate } \\
\text { leaching } \\
\text { using } \\
\text { extraction } \\
\text { coefficient }\end{array}$ & Grid based & Hourly & $N$ and $P$ & {$[93,121]$} \\
\hline TNT2 & $\begin{array}{l}\text { Process } \\
\text { based }\end{array}$ & $\begin{array}{l}\text { Soil-ground } \\
\text { water and } \\
\text { surface } \\
\text { interaction }\end{array}$ & - & Exist & Grid based & $\begin{array}{l}\text { Variable } \\
\text { steps }\end{array}$ & $N$ & [140] \\
\hline SHETRAN & $\begin{array}{c}\text { Process } \\
\text { based }\end{array}$ & EPIC model & Exist & Exist & Grid based & $\begin{array}{l}\text { Variable } \\
\text { steps }\end{array}$ & $\mathrm{NO}_{3}-\mathrm{N}$ & {$[107,108,110]$} \\
\hline $\begin{array}{l}\text { MIKESHE/ } \\
\text { DAISY }\end{array}$ & $\begin{array}{l}\text { Process } \\
\text { based }\end{array}$ & DAISY & - & $\begin{array}{l}\text { Solute } \\
\text { transport } \\
\text { process }\end{array}$ & Grid based & $\begin{array}{l}\text { Variable } \\
\text { steps }\end{array}$ & $\mathrm{NO}_{3}-\mathrm{N}$ & $\begin{array}{c}{[13,41-} \\
43,107,108]\end{array}$ \\
\hline IISDHM & $\begin{array}{l}\text { Process } \\
\text { based }\end{array}$ & $\begin{array}{l}\text { Flow } \\
\text { capacity } \\
\text { based }\end{array}$ & Dynamic & Lumped & Grid based & $\begin{array}{l}\text { Run in } 1 \mathrm{~s} \\
\text { time step } \\
\text { with hourly } \\
\text { interval } \\
\text { output }\end{array}$ & $\begin{array}{l}N \text { and } P \\
\text { species }\end{array}$ & [131-136] \\
\hline
\end{tabular}




\section{References}

1. DEFRA. Mapping the Problem Risks of Diffuse Water Pollution from Agriculture; Department for Environment, Food and Rural Affairs: London, UK, 2004.

2. Lu, F.-H.; Ni, H.-G.; Liu, F.; Zeng, E.Y. Occurrence of nutrients in riverine runoff of the Pearl River Delta, South China. J. Hydrol. 2009, 376, 107-115. [CrossRef]

3. Croke, J. Managing Phosphorus in Catchment. In River Landscapes; Fact Sheet11; Land \& Water: Canberra, Australia, 2002.

4. Bennett, E.M.; Carpenter, S.R.; Caraco, N.F. Human impact on erodable phosphorus and eutrophication: A global perspective. Bioscience 2001, 51, 227-234. [CrossRef]

5. Boyer, E.W.; Howarth, R.W.; Galloway, J.N.; Dentener, F.J.; Green, P.A.; Vörösmarty, C.J. Riverine nitrogen export from the continents to the coasts. Glob. Biogeochem. Cycles 2006, 20, GB1S91. [CrossRef]

6. Galloway, J.N.; Dentener, F.J.; Capone, D.G.; Boyer, E.W.; Howarth, R.W.; Seitzinger, S.P.; Asner, G.P.; Cleveland, C.C.; Green, P.A.; Holland, E.A.; et al. Nitrogen Cycles: Past, Present, and Future. Biogeochemistry 2004, 70, 153-226. [CrossRef]

7. Meybeck, M. Carbon, nitrogen, and phosphorus transport by world rivers. Am. J. Sci. 1982, 282, 401-405. [CrossRef]

8. Chen, M.; Chen, J.; Du, P. An inventory analysis of rural pollution loads in China. Water Sci. Technol. 2006, 54, 65-74. [CrossRef] [PubMed]

9. Hannam, P. World of Hurt': Toxic Blooms Take over Lower Darling River as Dam Debate Ramps up, the Sydney Morning Herald, Published on 25 February 2021. Lower Darling River Taken over by Toxic Cyanobacterial Blooms as Dam Debate Ramps up. Available online: smh.com.au (accessed on 26 February 2021).

10. OECD. Highlights of the OECD Environmental Outlook; OECD Publications: Paris, France, 2001.

11. IPCC. Climate Change and Water; Technical Report VI; Inter Governmental Panel on Climate Change (IPCC), IPCC Secretariat: Geneva, Switzerland, 2008; p. 210. ISBN 978-92-9169-123-4.

12. Dewalle, D.R.; Buda, A.R.; Eismeier, J.E.; Sharpe, W.E.; Swistock, B.R.; Craig, P.L.; O' Driscoll, M.A. Nitrogen cycling on five headwater forested catchments in Mid- ppalachians of Pennsylvania. Dynamics and Biogeochemistry of River Corridors and Wetlands. In Proceedings of the Seventh IAHS Scientific Assembly, Foz do Iguaçu, Brazil, 3-9 April 2005.

13. Hertel, O.; Skjøth, C.A.; Løfstrøm, P.; Geels, C.; Frohn, L.M.; Ellermann, T.; Madsen, P.V. Modelling Nitrogen Deposition on a Local Scale-A Review of the Current State of the Art. Environ. Chem. 2006, 3, 317-337. [CrossRef]

14. Aber, J.D.; Goodale, C.L.; Ollinger, S.V.; Smith, M.L.; Magill, A.H.; Martin, M.E.; Hallett, R.A.; Stoddard, J.L. Is Nitrogen Deposition Altering the Nitrogen Status of Northeastern Forests? BioScience 2003, 53, 375-389. [CrossRef]

15. Harris, G.P. Biogeochemistry of nitrogen and phosphorus in Australian catchments, rivers and estuaries: Effects of land use and flow regulation and comparisons with global patterns. Marine Freshw. Res. 2001, 52, 139-149. [CrossRef]

16. Tiller, D.; Newall, P. Preliminary Nutrient Guideline for Victorian Inland Streams; Publication 478; Environment Protection Authority, Government of Victoria: Melbourne, Australia, 1995. Available online: http:/ / www.epa.vic.gov.au (accessed on 5 February 2010).

17. Laniak, G.F.; Olchin, G.; Goodall, J.; Voinov, A.; Hill, M.; Glynn, P.; Whelan, G.; Geller, G.; Quinn, N.; Blind, M.; et al. Integrated environmental modeling: A vision and roadmap for the future. Environ. Model. Softw. 2013, 39, 3-23. [CrossRef]

18. Xu, H.; Wolanski, E.; Chen, Z. Suspended particulate matter affects the nutrient budget of turbid estuaries: Modification of the LOICZ model and application to the Yangtze Estuary. Estuar. Coast. Shelf Sci. 2013, 127, 59-62. [CrossRef]

19. Hirt, U.; Venohr, M.; Kreins, P.; Behrendt, H. Modelling nutrient emissions and the impact of nutrient reduction measures in the Weser river basin, Germany. Water Sci. Technol. 2008, 58, 2251-2258. [CrossRef] [PubMed]

20. Edgar, B. National Eutrophication Management Program: Highlights 1995-2001. "RipRap", River and Riparian Lands Management Newsletter; Land \& Water: Canberra, Australia, 2001; Volume 20, pp. 23-26.

21. Croke, J.; Young, B. River Contaminants: What are river contaminants and how can we effectively manage them for riverine and ecosystem protection? In "RipRap", River and Riparian Lands Management Newsletter; Land \& Water: Canberra, Australia, 2001; Volume 20, pp. 1-6.

22. Blind, M.W.; Moore, R.V.; Scholten, H.M.; Refsgaard, J.C.; Borowski, I.; Giupponi, C.; Estrela, M.; Vanrolleghem, P.A. Current Results of the EC-Sponsored Catchment Modelling (CatchMod) Cluster: Part 1: "Cross-Cutting Issues", IWA 2005; Watershed \& River Basin Management Specialist Group Conference: Calgary, AB, Canada, 2005.

23. Blind, M.W.; Borgvang, S.A.; George, D.G.; Froebrich, J.; Zsuffa, I.; Vanrolleghem, P.; Jørgensen, L.F.; de Lange, W.J. Current Results of the EC-Sponsored Catchment Modelling (CatchMod) Cluster: Part 2: "Water Topics and Synthesis" IWA 2005; Watershed \& River Basin Management Specialist Group Conference: Calgary, AB, Canada, 2005.

24. European Commission. Directive of the European Parliament and of the Council 2000/60/EC Establishing a Framework for Community Action in the Field of Water Policy. In Official Journal 2000 L 327/1; European Commission: Brussels, Belgium, 2000; p. 73.

25. ICSU (International Council for Science). Regional Environmental Change: Human Action and Adaptation; International Council for Science: Paris, France, 2010.

26. Schellekens, J.; Veldhuizen, A.A.; Manders, A.M.M.; Winsemius, H.C.M.; van Verseveld, W.J.; te Linde, A.H.; van Ulft, L.H.; van Meijgaard, E.; Schaap, M.; Barendregt, A.; et al. KKK-Model Platform Coupling. Summary Report KKF01b. Deltares, TNO, Alterra, VU Amsterdam, Universiteit Utrecht; KNMI: De Bilt, The Netherlands, 2011; Final Report KFC/038A/2011; ISBN 978-94-90070-00-7.

27. Borah, D.K.; Bera, M. Watershed-scale hydrologic and nonpoint source pollution models: Review of mathmatical bases. Trans. ASAE 2003, 46, 1553-1566. [CrossRef] 
28. Bennett, N.D.; Croke, B.F.W.; Guariso, G.; Guillaume, J.H.A.; Hamilton, S.H.; Jakeman, A.J.; Marsili-Libelli, S.; Newham, L.T.H.; Norton, J.P.; Perrin, C.; et al. Characterising performance of environmental models. Environ. Model. Softw. 2013, 40, 1-20. [CrossRef]

29. Fu, B.; Merritt, W.S.; Croke, B.F.W.; Weber, T.R.; Jakeman, A.J. A review of catchment-scale water quality and erosion models and a synthesis of future prospects. Environ. Model. Softw. 2019, 114, 75-97, ISSN 1364-8152. [CrossRef]

30. Whitehead, P.G.; Wilson, E.J.; Butterfield, D. A semi-distributed integrated nitrogen model for multiple source assessment in catchment. Part I. Model structure and process equations. Sci. Total Environ. 1998, 210-211, 547-558. [CrossRef]

31. Whitehead, P.G.; Wilson, E.J.; Butterfield, D.; Seed, K. A Semi-Distributed Integrated Flow and Nitrogen Model for Multiple Source Assessment in Catchments (Inca): Part II-Application to Large River Basins in South Wales and Eastern England. Sci. Total Environ. 1998, 210-211, 559-583. [CrossRef]

32. Liu, S.; Tucker, P.; Mansell, M.; Hursthouse, A. Development and application of acatchment scale diffuse nitrate modelling tool. Hydrol. Process. 2005, 19, 2625-2639. [CrossRef]

33. Zhang, D.; Chen, J.; Du, P.; He, W. An integrated system for nonpoint source pollution modelling and management. Water Sci. Technol. 2006, 54, 101-109. [CrossRef]

34. EPA. PLOAD Version 3.0; An ArcVIew GIS Tool to Calculate Nonpoint Sources of Pollution in Watershed and Stormwater Projects. User's Manual; United States Environmental Protection Agency: Washington, DC, USA, 2001.

35. Foster, G.R.; Lane, L.J.; Nowlin, J.D.; Laflen, J.M.; Young, R.A. Estimating erosion and sediment yield on field-sized areas. Trans. Am. Soc. Agric. Eng. 1981, 24, 1253-1263. [CrossRef]

36. Leonard, R.A.; Knisel, W.G.; Still, D.A. GLEAMS: Groundwater loading effects of agricultural management systems. Trans. ASAE 1987, 30, 1403-1418. [CrossRef]

37. Bergstrom, L.; Johnsson, H.; Torstensson, G. Simulation of soil nitrogen dynamics using the SOILN model. Fertil. Res. 1991, 27, 181-188. [CrossRef]

38. Johnsson, H.; Bergstorm, L.; Jansson, P.-E.; Paustian, K. Simulated nitrogen dynamics and losses in a layered agricultural soil. Agric. Ecosyst. Environ. 1987, 18, 333-356. [CrossRef]

39. Kyllmar, K.; Martensson, K.; Johnsson, H. Model-based coefficient method for calculation of $N$ leaching from agricultural fields applied to small catchments and the effects of leaching reducing measures. J. Hydrol. 2005, 304, 343-354. [CrossRef]

40. Jabro, J.D.; Jabro, A.D.; Fox, R.H. Accuracy and performance of three water quality models for simulating nitrate nitrogen losses under corn. J Environ Qual. 2006, 35, 1227-1236. [CrossRef]

41. Abrahamsen, P.; Hansen, S. Daisy: An open soil-crop-atmosphere system model. Environ. Model. Softw. 2000, 15, 313-330. [CrossRef]

42. Hansen, S.; Jensen, H.E.; Nielson, N.E.; Svendson, H. DAISY. A Soil Plant System Model. Danish Simulation Model for Transformation and Transport of Energy and Matter in the Soil Plant Atmosphere System. NPO-Research Report A 10; The National Agency of Environmental Protection: Copenhagen, Denmark, 1990.

43. Hansen, S.; Jensen, H.E.; Nielsen, N.E.; Svendsen, H. Simulation of nitrogen dynamics and biomass production in winter wheat using the Danish simulation model. Daisy Fert. Res. 1990, 27, 245-259. [CrossRef]

44. Ahuja, L.R.; Rojas, K.W.; Hanson, J.D.; Shaffer, M.J.; Ma, L. Root Zone Water Quality Model. Modeling Management Effects on Water Quality and Crop Production; Water Resource Publication: Highlands Ranch, CO, USA, 2000.

45. Ahuja, L.R.; Ma, Q.L.; Rojas, K.W.; Boeston, J.T.I.; Farahani, H.J. A field test of Root Zone Water Quality Model- Pesticide and bromide behaviour. Pesti. Sci. 1996, 48, 101-108. [CrossRef]

46. DeCoursey, D.G.; Ahuja, L.R.; Hanson, J.; Shaffer, M.; Nash, R.; Rojas, K.W.; Hebson, C.; Hodges, T.; Ma, Q.; Johssen, J.E.; et al. Root Zone Water Quality Model, Technical Documentation; Version 1.0; United States Department of Agriculture, Agricultural Research Service, Great Plains Systems Research Unit: Fort Collins, CO, USA, 1992.

47. Rojas, K.W.; Hebson, C.S.; Decoursey, D.G. Modelling agricultural management subject to sub surface water quality constraints. In Proceedings of the International Symposium Modelling Agriculture, Forest and Hydrology ASAE Winter Meeting, Chicago, IL, USA, 12-13 December 1988; ASAE: St. Joseph, MI, USA, 1988; pp. 108-116.

48. Schwartz, L.; Shuman, L.M. Predicting Runoff and Associated Nitrogen Losses from Turfgrass using the Root Zone Water Quality Model (RZWQM). Environ. Qual. 2005, 34, 350-358. [CrossRef]

49. Chapra, S.C.; Pelletier, G.J.; Tao, H. QUAL2K: A Modeling Framework for Simulating River and Stream Water Quality, Version 2.04. In Documentation and Users Manual; Civil and Environmental Engineering Dept, Tufts University: Medford, MA, USA, 2006.

50. Brown, L.C.; Barnwell, T.O. The Enhanced Stream Water Quality Models QUAL2E and QUAL2E-UNCAS, EPA/600/3-87-007; US Environmental Protection Agency: Athens, GA, USA, 1987; p. 189.

51. Chapra, S.C. Surface-Water Quality Modelling; WCB McGraw Hill: Columbus, OH, USA, 1997.

52. Radwan, M.; Willems, P.; El-Sadek, A.; Berlamont, J. Modelling of dissolved oxygen and biochemical oxygen demand in river water using a detailed and a simplified model. River Basin Manag. 2003, 1, 97-103. [CrossRef]

53. Brevé, M.; Skaggs, R.; Kandil, H.; Parsons, J.; Gilliam, J. DRAINMOD-N, a Nitrogen Model for Artificially Drained Soils. Trans. ASAE 1997, 40, 1067-1075. [CrossRef]

54. Martin, C.; Cardona, C.M.; Martin, D.S.; Salterain, A.; Ayesa, E. Dynamic simulation of the water quality in rivers based on the IWA RWQM1. Application of the new simulator CalHidra 2.0 to the Tajo River. Water Sci. Technol. 2006, 54, 75-83. [CrossRef] 
55. Young, R.A.; Onstad, C.A.; Bosch, D.D.; Anderson, W.P. AGNPS: A non point source pollution model for evaluating agricultural watersheds. J. Soil Water Conserv. 1989, 44, 168-173.

56. Foerster, J.; Milne-Home, W.A. Application of AGNPS to model nutrient gereneration rates under diferent farming management practices at the Gunnedah Research Centre catchment. Aust. J. Exp. Agric. 1995, 35, 961-967. [CrossRef]

57. Bosch, D.D.; Theurer, F.D.; Bingner, R.L.; Felton, G.; Chaubey, I. Evaluation of AnnAGNPS Water Quality Model, ASAE Paper No.982195. In Proceedings of the ASAE Annual International Meeting, Orlando, FL, USA, 12-16 July 1998.

58. Cronshey, R.G.; Theurer, F.D. AnnAGNPS-Non-point pollutant loading model. In Proceedings of the First Federal Interagency Hydrologic Modeling Conference, Las Vegas, NV, USA, 19-23 April 1998; pp. 1-16.

59. Theurer, D.F.; Cronshey, R.G. AnnAGNPS-Reach routing processes. In Proceedings of the First Federal Interagency Hydrologic Modeling Conference, Las Vegas, NV, USA, 19-23 April 1998; pp. 1-32.

60. Shrestha, S.; Babel, M.S.; Gupta, A.D.; Kazama, F. Evaluation of annualised agricultural nonpoint source model for a watershed in the Siwalik Hills of Nepal. Environ. Model. Softw. 2006, 21, 961-975. [CrossRef]

61. Beasley, D.B.; Huggins, L.F.; Monke, E.J. ANWERS: A model for watershed planning. Trans. ASAE 1980, 23, 938-944. [CrossRef]

62. Beasley, D.B.; Huggins, L.F.; Monke, E.J. Modeling sediment yield from agricultural watersheds. J. Soil Water Conserv. 1982, 37, 113-117.

63. De Roo, A.P.J.; Hazelhoff, I.; Burroh, P.A. Soil erosion modeling using ANSWERS and GIS. Earth Surf. Proc. Land 1989, 14, 517-532. [CrossRef]

64. Rewerts, C.C.; Engel, B.A. ANSWERS on GRASS: Integrating watershed simulation with a GIS. In ASAE Paper No. 91-2621; ASAE: St. Joseph, MI, USA, 1991.

65. Singh, R.; Tiwari, K.N.; Mal, B.C. Hydrological studies for small watershed in India using the ANSWERS model. J. Hydrol. 2006, 318, 184-199. [CrossRef]

66. Krysanova, V.; Mueller-Wohlfeil, D.-I.; Becker, A. Development and test of a spatially distributed hydrological/water quality model for mesoscale watersheds. Ecol. Model. 1998, 106, 261-289. [CrossRef]

67. Newham, L.T.H.; Letcher, R.A.; Jakeman, A.J.; Kobayashi, T. A framework for integrated hydrologic, sediment and nutrient export modelling for catchment-scale management. Environ. Model. Softw. 2004, 19, 1029-1038. [CrossRef]

68. Jakeman, A.J.; Littlewood, I.G.; Whitehead, P.G. Computation of the instantaneous unit hydrograph and identifiable component flows with application to two small upland catchments. J. Hydrol. 1990, 117, 275-300. [CrossRef]

69. Prosser, I.P.; Rustomji, P.; Young, W.J.; Moran, C.; Hughes, A. Constructing River Basin Sediment. Budgets for the National Land and Water Resources Audit; CSIRO Land and Water: Canberra, Australia, 2001.

70. Newham, L.T.H.; Drewry, J.J. Modelling catchment-scale nutrient generation. In Technical Report 28/05, National River Contaminants Program of Land and Water Australia; CSIRO Land and Water: Canberra, Australia, 2006.

71. Behrendt, H.; Kornmilch, M.; Opitz, D.; Schmoll, O.; Scholz, G. Estimation of the nutrient inputs into river systems-Experiences from German rivers. Reg. Environ. Chang. 2002, 3, 107-117. [CrossRef]

72. Venohr, M.; Behrendt, H.; Kluge, W. The effects of different input data and their spatial resolution on the results obtained from a conceptual nutrient emissions model: The River Stor case study. Hydrol. Process. 2005, 19, 3501-3515. [CrossRef]

73. Hoos, A.B.; McMahon, G. Spatial analysis of instream nitrogen loads and factors controlling nitrogen delivery to streams in the southeastern United States using spatially referenced regression on watershed attributes (SPARROW) and regional classification frameworks. Hydrol. Process. 2009. [CrossRef]

74. Singh, K.P.; Malik, A.; Sinha, S. Water quality assessment and apportionment of pollution sources of Gomti river (India) using multivariate statistical techniques: A case study. Anal. Chim. Acta 2005, 538, 355-374. [CrossRef]

75. Singh, K.P.; Malik, A.; Mohan, D.; Sinha, S. Multivariate statistical techniques for the evaluation of spatial and temporal variations in water quality of Gomti River (India): A case study. Water Res. 2004, 38, 3980-3992. [CrossRef] [PubMed]

76. Cuddy, S.; Marston, F.; Simmons, B.; Davis, R.; Farley, T. Applying CMSS in the Hawkesbury-Nepean Basin; CSIRO Division of Water Resources: Canberra, Australia, 1994; Volume 1.

77. Argent, R.M.; Perraud, J.M.; Rahman, J.M.; Grayson, R.B.; Podger, G.M. A new approach to water quality modelling and environmental decision support systems. Environ. Model. Softw. 2009, 24, 809-818. [CrossRef]

78. Donnelly, T.H.; Barnes, C.J.; Wasson, R.J.; Murray, A.S.; Short, D.L. Catchment phosphorus sources and algal blooms-an interpretative review. In CSIRO Land and Water Technical Report 18/98; CSIRO Land and Water: Canberra, Australia, 1998.

79. Baginska, B.; Pritchard, T.; Krogh, M. Roles of land use resolution and unit-area load rates in assessment of diffuse nutrient emissions. J. Environ. Manag. 2003, 69, 39-46. [CrossRef]

80. Cuddy, S.M.; Rahman, J.M.; Marston, F.M.; Seaton, S.P.; Vertessy, R.A. Alternative approaches to incorporating management options into water quality modelling. In Proceedings of the Third Stream Management Conference: The Value of Healthy Streams; Rutherfurd, I., Sheldon, F., Brierley, G., Kenyon, C., Eds.; Cooperative Research Centre for Catchment Hydrology, Melbourne: Brisbane, Australia, 2001; pp. 169-174.

81. Merritt, W.S.; Letcher, R.A.; Jakeman, A.J. A review of erosion and sediment transport models. Environ. Model. Softw. 2003, 18, 761-799. [CrossRef]

82. Hossain, I.; Imteaz, M.A.; Arulrajah, A.; Hossain, M.I. Continuous simulation of suspended sediment through a stream section. Int. J. Water 2013, 7, 206-222. [CrossRef] 
83. Imteaz, M.A.; Arulrajah, A.; Hossain, I.; Hossain, M.I. Estimation of Build and wash off models parameters for an East Australian cacthement. Int. J. Water 2014, 8, 48-62. [CrossRef]

84. Hewett, C.J.M.; Quinn, P.F.; Whitehead, P.G.; Heathwaite, A.L.; Flynn, N.J. Towards a nutrient export risk matrix approach to managing agricultural pollution at source. Hydrol. Earth Syst. Sci. 2004, 8, 834-845. [CrossRef]

85. Wade, A.J.; Whitehead, P.G.; Butterfield, D. The integrated catchments model of phosphorus dynamics (INCA-P), a new approach for multiple source assessment in heterogeneous river systems: Model structure and equations. Hydrol. Earth Syst. Sci. 2002, 6, 583-606. [CrossRef]

86. Billen, G.; Garnier, J.; Hanset, P. Modelling phytoplankton development in whole drainage network: The RIVERSTRAHLER Model applied to the Seine river system. Hydrobiologia 1994, 289, 119-137. [CrossRef]

87. Garnier, J.; Billen, G.; Coste, M. Seasonal succession of diatoms and chlorophyceae in the drainage network of the Seine river: Observations and modelling. Limnol. Oceanogr. 1995, 40, 750-765.

88. Garnier, J.; Ne'mery, J.; Billen, G.; Théry, S. Nutrient dynamics and control of eutrophication in the Marne River system: Modelling the role of exchangeable phosphorus. J. Hydrol. 2005, 304, 397-412. [CrossRef]

89. Garnier, J.; Billen, G.; Hannon, E.; Fonbonne, S.; Videnina, Y.; Soulie, M. Modeling transfer and retention of nutrients in the drainage network of the Danube river. Estuar Coast. Shelf Sci. 2002, 54, 285-308. [CrossRef]

90. Garnier, J.; Billen, G.; Palfner, L. Understanding the oxygen budget of the Mosel drainage network with the concept of heterotrophic/autotrophic sequences: The Riverstrahler approach. J. Hydrobiol. 1999, 410, 151-166. [CrossRef]

91. Garnier, J.; Leporcq, B.; Sanchez, N.; Philippon, X. Biogeochemical budgets in three large reservoirs of the seine basin (Marne, Seine and Aube reservoirs). J. Biogeochem. 1999, 47, 119-146.

92. De Wit, M.J.M. Nutrient fluxes at the river basin scale I: The PolFlow model. Hydrol. Process. 2001, 15, 743-759. [CrossRef]

93. Leon, L.F.; Soulis, E.D.; Kouwen, N.; Farquhar, G.J. Nonpoint source pollution: A distributed water quality modelling approach. Water Res. 2001, 35, 997-1007. [CrossRef]

94. Arnold, J.D.; Fohrer, N. SWAT2000: Current capabilities and research opportunities in applied watershed modelling. Hydrol. Process. 2005, 19, 563-572. [CrossRef]

95. Arnold, J.G.; Srinivasan, R.; Muttiah, R.S.; Williams, J.R. Large area hydrologic modelling and assessment part I: Model development. J. Am. Water Resour. Assoc. 1998, 34, 73-89. [CrossRef]

96. Knisel, W.G. A Field-Scale Model for Chemicals, Runoff and Erosion from Agricultural Management Systems; Research Report 26; USDA: Washington, DC, USA, 1980; p. 640.

97. Knisel, W.G.; Williams, J.R. Hydrology component of CREAMS and GLEAMS models. In Computer Models of Watershed Hydrology; Singh, V., Ed.; Water Resources Publication: Denver, CO, USA, 1995.

98. Izaurralde, R.C.; Williams, J.R.; McGill Rosenberg, W.B.; Quirogas, N.J.; Jakas, M.C. Simulating soil C dynamics with EPIC: Model description and testing against long-term data. Ecol. Model. 2006, 192, 362-384. [CrossRef]

99. Williams, J.R.; Renard, K.G.; Dyke, P.T. EPIC—A new model for assessing erosion's effect on soil productivity. J. Soil Water Conserv. 1984, 38, 381-383.

100. Arnold, J.G.; Williams, J.R. Validation of SWRRB: Simulator for water resources in rural basins. J. Water Resour. Plan. Manag. 1987, 113, 243-256. [CrossRef]

101. Behera, S.; Panda, R. Evaluation of management alternatives for an agricultural watershed in a sub-humid subtropical region using a physical process based model. Agric. Ecosyst. Environ. 2006, 113, 62-72. [CrossRef]

102. Yang, S.; Dong, G.; Zheng, D.; Xiao, H.; Gao, Y.; Lang, Y. Coupling Xinanjiang model and SWAT to simulate agricultural nonpoint source pollution in Songtao watershed of Hainan, China. Ecol. Model. 2011, 222, 3701-3717. [CrossRef]

103. Beven, K.J.; Wood, E.F.; Sivapalan, M. On hydrological heterogeneity-catchment morphology and catchment response. J. Hydrol. 1988, 100, 353-375. [CrossRef]

104. Krysanova, V.; Luik, H. Simulation Modelling of a System Watershed-River-Sea Bay; Valgus: Tallinn, Estonia, 1989; p. 428. (In Russian)

105. Krysanova, V.; Meiner, A.; Roosaare, J.; Vasilyev, A. Simulation modeling of the coastal waters pollution from agricultural watershed. Ecol. Modell. 1989, 49, 7-29. [CrossRef]

106. Galbiati, L.; Bouraoui, F.; Elorza, F.J.; Bidoglio, G. Modelling diffuse pollution into a Mediterranean lagoon: Development and application of an integrated surface-subsurface model tool. Ecol. Model. 2006, 193, 4-18. [CrossRef]

107. Abbott, M.B.; Bathurst, J.C.; Cunge, J.A.; O'Connell, P.E.; Rasmussen, J. An introduction to the European Hydrological SystemSysteme Hydrologique Europeen, 'SHE', 1: History and philosophy of a physically based modelling system. J. Hydrol. 1986, 87, 45-59. [CrossRef]

108. Abbott, M.B.; Bathurst, J.C.; Cunge, J.A.; O'Connell, P.E.; Rasmussen, J. An introduction to the European Hydrological SystemSysteme Hydrologique Europeen, 'SHE', 2: Structure of a physically based distributed modelling system. J. Hydrol. 1986, 87, 67-77. [CrossRef]

109. Birkinshaw, S.J.; Ewen, J. Nitrogen transformation component for SHETRAN catchment nitrate transport modelling. J. Hydrol. 2000, 230, 1-17. [CrossRef]

110. Ewen, J. Contaminant transport component of the catchment modelling system SHETRAN. In Solute Modelling in Catchment Systems; Trudgill, S.T., Ed.; John Wiley \& Sons: Chichester, UK, 1995; pp. 417-441.

111. Jones, C.A.; Dyke, P.T.; Williams, J.R.; Kiniry, J.R.; Benson, V.W.; Griggs, R.H. EPIC: An operational model for the evaluation of agricultural sustainability. Agric. Syst. 1991, 37, 341-350. [CrossRef] 
112. Lunn, R.J.; Adams, R.; Dunn, S.M. Development and application of a nitrogen modelling system for large catchments. Hydrology 1996, 174, 285-304. [CrossRef]

113. Christiansen, J.S.; Thorsen, M.; Clausen, T.; Hansen, S.; Refsgaard, J.C. Modelling of macropore flow and transport processes at catchment scale. J. Hydrol. 2004, 299, 136-158. [CrossRef]

114. Refsgaard, J.C.; Thorsen, M.; Jensen, J.B.; Kleeschulte, S.; Hansen, S. Large scale modelling of groundwater contamination from nitrate leaching. J. Hydrol. 1999, 211, 117-140. [CrossRef]

115. Styczen, M.; Storm, B. Modelling of $N$-movements on catchment scale-A tool for analysis and decision making. 1 . Model description. Fert. Res. 1993, 36, 1-6. [CrossRef]

116. Styczen, M.; Storm, B. Modelling of $\mathrm{N}$-movements on catchment scale-A tool for analysis and decision making. 2. A case study. Fert. Res. 1993, 36, 7-17. [CrossRef]

117. Morgan, R.P.C.; Quinton, J.N.; Smith, R.E.; Govers, G.; Poesen, J.W.A.; Auerswald, K.; Chisci, G.; Torri, D.; Styczen, M.E. The European Soil Erosion Model (EUROSEM): A dynamic approach for predicting sediment transport from fields and small catchments. Earth Surf. Process Land Form 1998, 23, 527-544. [CrossRef]

118. Morgan, R.P.C.; Quinton, J.N.; Smith, R.E.; Govers, G.; Poesen, J.W.A.; Auerswald, K.; Chisci, G.; Torri, D.; Styczen, M.E.; Folley, A.J.V. The European Soil Erosion Model. (EUROSEM): Documentation and User Guide; Version 3.6; Silsoe College, Cranfield University: Cranfield, UK, 1998.

119. Arnold, J.G.; Williams, J.R.; Nicks, A.D.; Sammons, N.B. SWRRB-A Basin Scale Simulation Model for Soil and Water Resources Management; Texas A\&M University Press: College Station, TX, USA, 1990; p. 255.

120. Arnold, J.G.; Allen, P.M.; Bernhardt, G. A comprehensive surface-groundwater flow model. J. Hydrol. 1993, 142, 47-69. [CrossRef]

121. Kouwen, N. WATFLOOD/SPL8 Flood Forecasting System, Documentation and User Manual; Civil Engineering, University of Waterloo: Waterloo, ON, Canada, 1999.

122. Chen, E.; Mackay, D.S. Effects of distribution-based parameter aggregation on a spatially distributed agricultural nonpoint source pollution model. Hydrology 2004, 295, 211-224. [CrossRef]

123. Rijtema, P.E.; Kroes, G.J. Some results of nitrogen simulations with the model ANIMO. Fertil. Res. 1991, 27, 189-198. [CrossRef]

124. Everbecq, E.; Gosselain, V.; Viroux, L.; Descy, J.P. Potamon: A dynamic model for predicting phytoplankton composition and biomass in lowland rivers. Water Res. 2001, 35, 901-912. [CrossRef]

125. Krysanova, V.; Becker, A. Integrated Modelling of Hydrological Process and Nutrient Dynamics at the River Basin Scale. Hydrobiologia 1999, 410, 131-138. [CrossRef]

126. Sferratore, A.; Billen, G.; Garnier, J.; Thery, S. Modelling Nutrient (N,P,Si) Budget in the Seine Watershed: Application of the Riverstrahler Model Using Data from Local to Global Scale Resolution. Glob. Biogechem. Cycles 2005, 19 , GB4S07.

127. Thouvenot, M.; Billen, G.; Garnier, J. Modelling Nutrient Exchange at the Sediment Water Interface of River Systems. Hydrology 2007, 341, 55-78. [CrossRef]

128. Miller, J.D.; Hutchins, M. The impacts of urbanisation and climate change on urban flooding and urban water quality: A review of the evidence concerning the United Kingdom. J. Hydrol. Reg. Stud. 2017, 12, 345-362. [CrossRef]

129. Whitehead, P.G.; Battarbee, R.W.; Crossman, J.; Elliott, J.A.; Wilby, R. A climate change report card for water Working Technical Paper 9. In River and Lake Water Quality-Future Trends; NERC Centre for Ecology \& Hydrology: Lancaster, UK, 2013 ; pp. 1-39.

130. Uktag. River Flow for Good Ecological Potential Final Recommendations. 2013. Available online: www.wfduk.org (accessed on 10 August 2021).

131. Dutta, D.; Nakayama, K. Effects of spatial grid resolution on river flow and surface inundation simulation by physically based distributed modeling approach. Hydrol. Process. 2009, 23, 534-545. [CrossRef]

132. Dutta, D.; Herath, S.; Musiake, K. Flood inundation simulation in a river basin using a physically based distributed hydrologic model. Hydrol. Process. 2000, 14, 497-519. [CrossRef]

133. Jha, R.; Herath, S.; Musiake, K. River network solution for a distributed hydrological model and applications. Hydrol. Process. 2000, 14, 575-592. [CrossRef]

134. Alam, M.J.; Dutta, D. Predicting climate change impact on nutrient pollution in waterways: A case study in the upper catchment of the Latrobe River, Australia. Ecohydrology 2013, 6, 73-82. [CrossRef]

135. Alam, M.J.; Dutta, D. A process-based and distributed model for nutrient dynamics in river basin: Development, testing and applications. Ecol. Model. 2012, 247, 112-124. [CrossRef]

136. Alam, M.J.; Dutta, D. A sub-catchment-based approach for modelling nutrient dynamics and transport at a river basin scale. Water Resour. Manag. 2016, 30, 5455-5478. [CrossRef]

137. Wagenet, R.J.; Huston, J.A. LEACHM: Leaching Estimation and Chemistry Model-A Process Based Model of Water and Solute Movement, Transformations, Plant Uptake and Chemical Reactions in the Unsaturated Zone; Version 2; Centre for Environmental Research, Department of Agronomy, Cornell University: Ithaca, NY, USA, 1989; p. 148.

138. Johnsson, H.; Larsson, M.; Martensson, K.; Hoffmann, M. SOILNDB: A decision support tool for assessing $N$ leaching losses from arable land. Environ. Model. Softw. 2002, 17, 505-517. [CrossRef]

139. DHI. MIKE11: A Modelling System for Rivers and Channels', Reference Manual; DHI Water \& Environment: Hørsholm, Denmark, 2002.

140. Ferrant, S.; Oehler, F.; Durand, P.; Ruiz, L.; Salmon-Monviola, J.; Justes, E.; Dugast, P.; Probst, A.; Probst, J.-L.; Sanchez-Perez, J.-M. Understanding nitrogen transfer dynamics in a small agricultural catchment: Comparison of a distributed (TNT2) and a semi distributed (SWAT) modeling approaches. Hydrology 2011, 406, 1-15. [CrossRef] 